\title{
Author Correction: Information-based autonomous reconfiguration in systems of interacting DNA nanostructures
}

\author{
Philip Petersen', Grigory Tikhomirov (10 ${ }^{2}$ \& Lulu Qian (10) 2,3
}

Correction to: Nature Communications; https://doi.org/10.1038/s41467-018-07805-7; published online: 18 December 2018

The original version of this Article omitted a reference to previous work in 'Stojanovic, M. N. \& Stefanovic, D. A deoxyribozyme-based molecular automaton. Nat. Biotechnol. 21, 1069-1074 (2003)'. This has been added as reference 42 . The following has been added after the third sentence of the fifth paragraph of the Discussion: 'Integration could also allow more sophisticated information processing, for example as shown by the classic deoxyribozyme-based automaton that plays tic-tac-toe ${ }^{42}$, to direct structural reconfiguration (Supplementary Discussion)'. This has been corrected in the PDF and HTML versions of the Article.

Published online: 22 January 2019

\footnotetext{
(c) Open Access This article is licensed under a Creative Commons Attribution 4.0 International License, which permits use, sharing, adaptation, distribution and reproduction in any medium or format, as long as you give appropriate credit to the original author(s) and the source, provide a link to the Creative Commons license, and indicate if changes were made. The images or other third party material in this article are included in the article's Creative Commons license, unless indicated otherwise in a credit line to the material. If material is not included in the article's Creative Commons license and your intended use is not permitted by statutory regulation or exceeds the permitted use, you will need to obtain permission directly from the copyright holder. To view a copy of this license, visit http://creativecommons.org/licenses/by/4.0/.
}

(c) The Author(s) 2019

\footnotetext{
${ }^{1}$ Biology, California Institute of Technology, Pasadena, CA 91125, USA. ${ }^{2}$ Bioengineering, California Institute of Technology, Pasadena, CA 91125, USA.

${ }^{3}$ Computer Science, California Institute of Technology, Pasadena, CA 91125, USA. These authors contributed equally: Philip Petersen, Grigory Tikhomirov.

Correspondence and requests for materials should be addressed to L.Q. (email: luluqian@caltech.edu)
} 